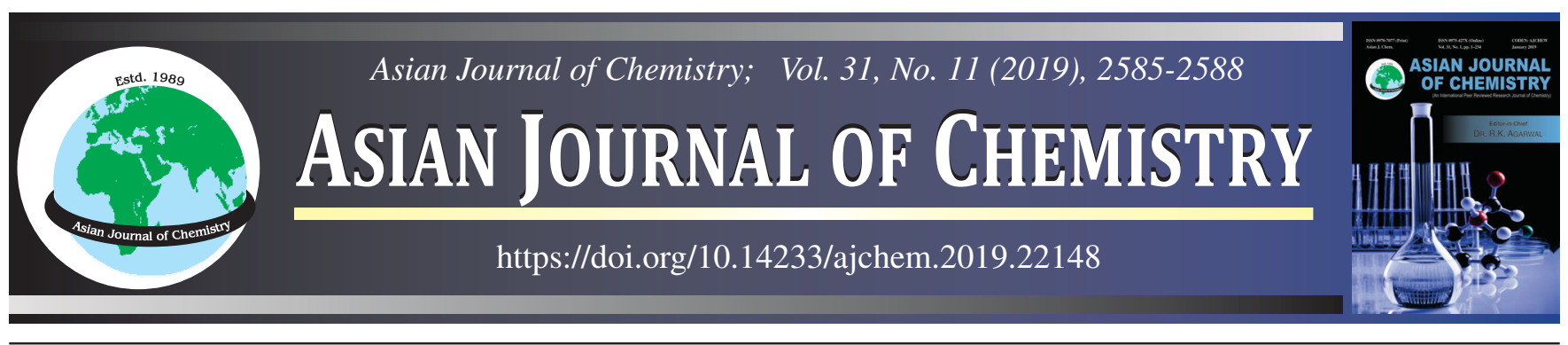

\title{
Essential Oil Hydrodistillation Process from Vietnamese Calamondin (Citrus microcarpa) Peels and GC/MS Analysis of Essential Oils Components
}

\author{
Ngo Thi Cam Quyen ${ }^{1,2}$, Tran Thi Kim Ngan ${ }^{2,3}$, Tan Phat Dao ${ }^{1,2}$, Phan Nguyen Quynh Anh ${ }^{4}$, Ngo Quoc Anh ${ }^{5,6}$, \\ Ngoc-Tram Nguyen Thi ${ }^{7}$, Thuy Trang Le NGoc ${ }^{8}$, Le Thi Hong Nhan ${ }^{4, *}$, Tran Thanh Truc ${ }^{9}$ and Le Thi Bich Phuong ${ }^{9, *}$ \\ ${ }^{1}$ Center of Excellence for Biochemistry and Natural Products, Nguyen Tat Thanh University, Ho Chi Minh City, Vietnam \\ ${ }^{2}$ NTT Hi-Tech Institute, Nguyen Tat Thanh University, Ho Chi Minh City, Vietnam \\ ${ }^{3}$ Faculty of Chemical Engineering and Food Technology, Nguyen Tat Thanh University, Ho Chi Minh City, Vietnam \\ ${ }^{4}$ Department of Chemical Engineering, HCMC University of Technology, VNU-HCM, Ho Chi Minh City,Vietnam \\ ${ }^{5}$ Graduate University of Science and Technology, Vietnam Academy of Science and Technology, Hanoi, VietNam \\ ${ }^{6}$ Institute of Chemistry, Vietnam Academy of Science and Technology, Hanoi, Vietnam \\ ${ }^{7}$ Tra Vinh University, No. 126, Nguyen Thien Thanh, Ward 5, Tra Vinh City, Tra Vinh Province 940000, Vietnam \\ ${ }^{8}$ Institute of Applied Materials Science, Vietnam Academy of Science and Technology, 01 TL29, District 12, Ho Chi Minh City, Vietnam \\ ${ }^{9}$ College of Agriculture, Can Tho University, Can Tho City, Vietnam
}

*Corresponding authors: E-mail: 1thnhan@hcmut.edu.vn; bichphuong@ctu.edu.vn

Received: 24 April 2019;

Accepted: 6 July 2019;

Published online: 28 September 2019;

AJC-19590

The essential oil of Citrus microcarpa peels was applied in many fields, and the methods to improve the efficiency of citrus exploitation were increasingly concerned. In this study, citrus essential oil was extracted from calamondin by hydrodistillation. This study was carried out to investigate the factors affecting the distillation of essential oils. The highest performance of the distillation process was $2.45 \%$ with optimal conditions (material-water ratio of $1: 3 \mathrm{~g} / \mathrm{mL}$, time of $2 \mathrm{~h}$, the temperature of $120^{\circ} \mathrm{C}$ ). Moreover, calamondin (Citrus microcarpa) peels oil extract was analyzed by gas chromatography-mass spectrometry (GC-MS). The primary compound of calamondin essential oil include limonene $96.925 \%, \beta$-myrcene $1.424 \%, 1 \mathrm{R}$ - $\alpha$-pinene $0.561 \%$, cyclohexene $0.343 \%$, $1 \mathrm{R}$ - $\alpha$-pinene $0.561 \%$ and $\beta$-cubebene $0.598 \%$.

Keywords: Essential oils, Hydrodistillation process, Calamondin (Citrus microcarpa).

\section{INTRODUCTION}

Today, the use of aromatic compounds of natural origin seems to become the trend and the research works on them are constantly developing [1-9]. Moreover, the efficiency of these products is quite high compared to other similar synthetic products. Through the available research and actual consumption shows that when using plant-based products, it has little harmful side effects, which is also the reason why the products are growing [10-14]. Vietnam has favourable natural conditions for the development of fruits, ornamental plants and a variety of valuable essential oil plants. In particular, citrus plants are very potential plants but have not been exploited and appropriately utilized. Citrus essential oils (grapefruit, lemon, orange, kumquat) has a characteristic aroma and sweet taste. Mainly, limonene accounted for over $90 \%$ of the total essential oil content and is widely used sprayed in food, pharmaceuticals, and cosmetics [15-22]. In Vietnam, especially in Mekong Delta, kumquat trees are a species of citrus species, the typical family of Rutaceae, grown throughout the place. Calamondin (Citrus microcarpa Lour) is a member of the Rutaceae family [23-25]. It is widely cultivated in tropical and subtropical areas, including China, Vietnam and Malaysia. The fruit is quite small, approximately $2.5-3.5 \mathrm{~cm}$ in diameter and has thin peels.

Among various methods for isolating essential oils from plants, hydrodistillation figures due to simplicity, ease of implementation and relatively high oil recovery efficiency [26-29]. In this method, vapours emitted by heating from the mixture of plant materials and solvent were liquefied in a condenser. Hydrodistillation method plays a vital role in the acquisition

This is an open access journal, and articles are distributed under the terms of the Attribution 4.0 International (CC BY 4.0) License. This license lets others distribute, remix, tweak, and build upon your work, even commercially, as long as they credit the author for the original creation. You must give appropriate credit, provide a link to the license, and indicate if changes were made. 
of important compounds used in food and plastic industries. In addition, the method also crucial in plant protection owing to its indispensability in manufacturing of antifungals, antivirals, and insecticides.

This study aimed to investigate the effects of extraction time $(75,90,105,120$ and $135 \mathrm{~min})$, material-to-water ratio $(1: 2,1: 3,1: 4$ and $1: 5 \mathrm{~mL} / \mathrm{g})$ and extraction temperature (100, $110,120,130$, and $140{ }^{\circ} \mathrm{C}$ ) on the yield of essential oil from Citrus microcarpa using single factor experiment. Moreover, we also determine the volatile constituents of essential oils from the leaf of Citrus microcarpa cultivated in Vietnam using GC-MS.

\section{EXPERIMENTAL}

The fresh Citrus microcarpa (Calamondin) were gathered in February 2019 from at Ben Tre province (latitudes $10^{\circ} 14^{\prime} 54^{\prime \prime} \mathrm{N}$ and longitudes $106^{\circ} 22^{\prime} 34^{\prime \prime} \mathrm{E}$ ), Vietnam. Calamondin were peeled to separated the external part, giving a peel yield of 15-20\% $(\mathrm{w} / \mathrm{w})$ relative to the whole fruit.

Extraction procedure: To extract the essential oil by hydrodistillation, first, $50 \mathrm{~g}$ of green pepper seed were washed and ground and mixed with $1 \mathrm{~L}$ distilled water. Clevenger extraction was operated for 30-240 min. The raw essential oil is separated to obtain the extraction oil which was dried with $\mathrm{Na}_{2} \mathrm{SO}_{4}$.

The yield of black pepper oil obtained (\%) is calculated as follows:

$$
\begin{aligned}
& \text { Yield of essential oil was obtained }(\%)= \\
& \frac{\text { Volume of essential oil obtained }(\mathrm{mL})}{\text { Amount of raw materials used }(\mathrm{g})} \times 100
\end{aligned}
$$

Gas chromatography-mass spectrometry analysis (GCMS): The composition of the obtained essential oils was determined using GC-MS. A sample of essential oil $(25 \mu \mathrm{L})$ in 1.0 $\mathrm{mL} n$-hexane was taken. The used instrument was GC Agilent 6890N, MS 5973 inert with HP5-MS column, head column pressure 9.3 psi. Following conditions was set to operate GCMS: carrier gas of He; flow rate $1.0 \mathrm{~mL} / \mathrm{min}$; split 1:100; injection volume $1.0 \mu \mathrm{L}$; injection temperature $250{ }^{\circ} \mathrm{C}$; oven temperature progress included an initial hold at $50^{\circ} \mathrm{C}$ for $2 \mathrm{~min}$, then increased by $2{ }^{\circ} \mathrm{C} / \mathrm{min}$ to $80^{\circ} \mathrm{C}$, and increased by $5^{\circ} \mathrm{C} / \mathrm{min}$ to $150{ }^{\circ} \mathrm{C}$, which continue rising to $200{ }^{\circ} \mathrm{C}$ at $10^{\circ} \mathrm{C} / \mathrm{min}$ and rise to $300^{\circ} \mathrm{C}$ at $20^{\circ} \mathrm{C} / \mathrm{min}$ for $5 \mathrm{~min}$.

\section{RESULTS AND DISCUSSION}

Single factor investigation: Fig. 1 illustrates the effect of different factors on the extraction of calamondin oil. First, liquid-solid ratio varied to study the effect of water-to-material ratio on extraction yield. Fig. 1A showed a clear turning point of yield as the ratio increases. To be specific, increasing waterto-material ratio from 2 to $3 \mathrm{~mL} / \mathrm{g}$ rises the yield to approximately $2.5 \%$. In contrast, higher dilution of the solution upto $5 \mathrm{~mL} / \mathrm{g}$ was associated with decreasing yield, reaching the minimum oil content at $1.8 \%$. During an extraction by hydrodistillation, the heat of electric stove will osmose within the material, breaking bags of essential oils and entraining the oils by steam. If the amount of water is insufficient to dissolve the mixture and salt-wrapped bags of essential oil, oil cannot escape from the oil. With increased use of water, diffusion of oil into the water could be improved, facilitating water absorption into the material and increasing obtainable soluble components. However, excessive water dissolves the oil, reducing the amount of oil obtained and in turn the economic efficiency of the extraction process due to increased energy consumption and prolonged time of heat extraction [30]. Therefore, the ratio of material-to-water (1:3) is selected as the optimal ratio.

Fig. 1B illustrates the effects of temperature on calamondin oil yield. There was an increase in the oil yield from 1.9 to 2.0 $\%$ as temperature is elevated from 100 to $120^{\circ} \mathrm{C}$. The explanation that higher heat levels could exert a more significant pressure gradient to the material, rapidly promoting the essential oil out of the glands. Besides, increasing the amount of heat will cause the oil to drain more, increasing the extraction efficiency of the essential oil. Visually, the escape rate for essential oils in saturated oil bag was shown to be capped at $2 \%$, corresponding with temperature of 120 and $130^{\circ} \mathrm{C}$ [31]. Therefore, $120^{\circ} \mathrm{C}$ is selected as the optimal distillation temperature.

Fig. 1C demonstrated the effect of extraction time on yield. The recommended time for extraction is $120 \mathrm{~min}(2.45 \%$ oil yield). Longer hydrodistillation is not economical because the essential oil content is apparently exhausted after $120 \mathrm{~min}$. In addition, when being exposed under thermal treatment in a long time, diffused essential oils in the cells might get dragged through steam. Conversely, short hydrodistillation duration may curb the yield. The yield essential oil used hydrodistillation method is equivalent to that of another study [32]. Therefore, $2 \mathrm{~h}$ is the optimal distillation time.
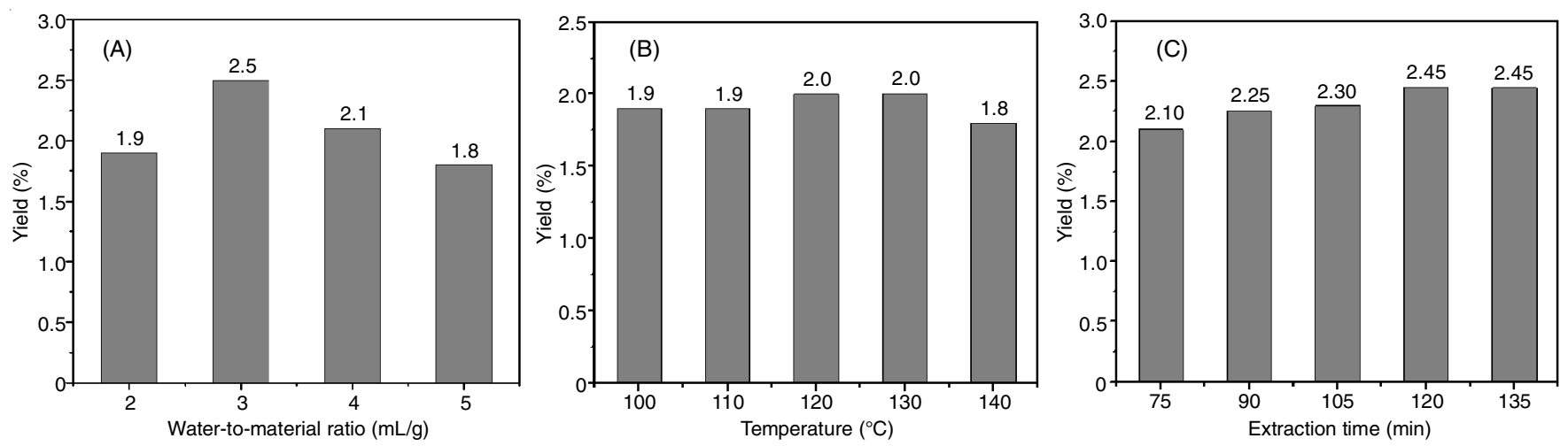

Fig. 1. Influence of factors on the yield of essential oil (A) water-to-material ratio, (B) temperature, (C) extraction time 
GC-MS analysis: Fig. 2 shows the results of GC-MS analysis for calamondin essential oil. Six compounds were characterized and identified according to the chromatogram (Table-1). Detected monoterpene hydrocarbons included limonene $96.925 \%$, $\beta$-myrcene $1.424 \%$, 1R- $\alpha$-pinene 0.561 $\%$, cyclohexene $0.343 \%, 1 \mathrm{R}-\alpha$-pinene $0.561 \%$ and $\beta$-cubebene $0.598 \%$. Compared to previous studies, calamondin peel oil contains limonene at a significantly higher content than other calamondin cultivars. For $\beta$-myrcene, the compound was found in lower quantity in comparison with materials from China and Mexico. It is also worth noting that unlike other calamondin cultivars, Vietnamese calamondin has an additional $\beta$-cubebene component, which is mostly found on the leaves of the calamondin tree [33]. The previous study demonstrates that the element in the essential oil from calamondin peel was limonene $(93.73 \%)$ [34]. The low content of terpene compounds (camphene, dcarene, limonene and $\alpha$-terpinene) is explained by another study suggesting that elevated temperatures could turn terpene compounds into other terpene hydrocarbons and oxide terpenes [35]. The chemical composition of essential oil is complex, unstable and always changes with the climatic condition and time in which the plant grows.

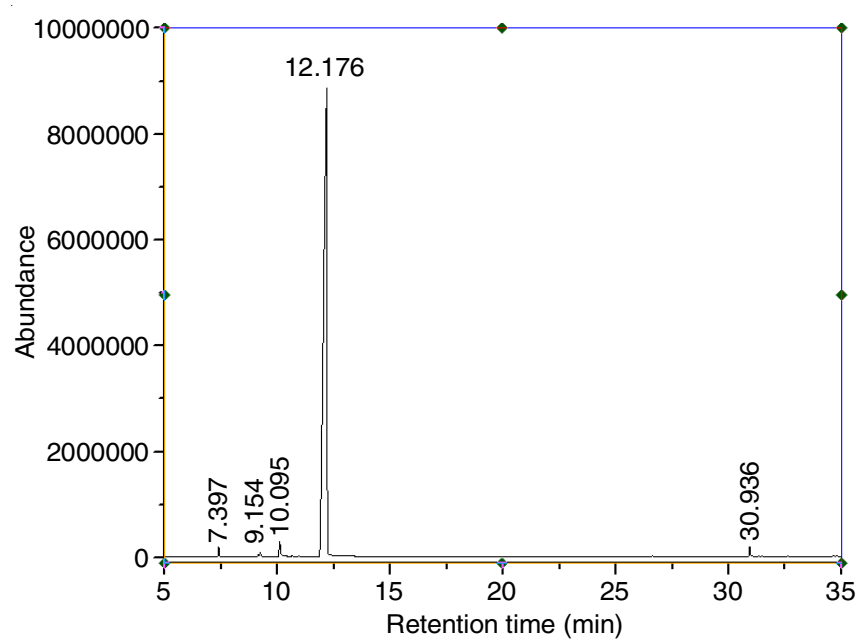

Fig. 2. GC-MS chromatogram of essential oil of Vietnamese calamondin (Citrus microcarpa)

\begin{tabular}{cccccc}
\multicolumn{7}{c}{ TABLE-1 } \\
\multicolumn{7}{c}{ VOLATILE CONSTITUENTS OF CALAMONDIN OIL } \\
\hline \multirow{2}{*}{ Peak } & $\begin{array}{c}\text { R.T. } \\
(\mathrm{min})\end{array}$ & \multicolumn{1}{c}{ Name } & $\begin{array}{c}\text { This } \\
\text { study }\end{array}$ & $\begin{array}{c}\text { China } \\
{[22]}\end{array}$ & $\begin{array}{c}\text { Mexico } \\
{[17]}\end{array}$ \\
\hline 1 & 7.397 & 1R- $\alpha$-Pinene & 0.561 & 0.53 & 1.10 \\
2 & 9.154 & $\beta$-Terpinene & 0.149 & $<0.01$ & nd \\
3 & 9.238 & Cyclohexene & 0.343 & nd & nd \\
4 & 10.095 & $\beta$-Myrcene & 1.424 & 2.08 & 4.20 \\
5 & 12.176 & Limonene & 96.925 & 92.70 & 77.00 \\
6 & 30.936 & $\beta$-Cubebene & 0.598 & nd & 0.10 \\
\hline nd $=$ not detected & & & &
\end{tabular}

\section{Conclusion}

In this study, calamondin (Citrus microcarpa) essential oil was extracted by hydrodistillation. Parameters involved in the hydrodistillation processing such as extraction time, temperature, the solvent to solid ratio have been taken into account to optimize operating conditions. In this study, the highest performance of the distillation process was $2.45 \%$ with optimal conditions (material-water ratio of $1: 3 \mathrm{~g} / \mathrm{mL}, 2 \mathrm{~h}$ and the temperature of $\left.120^{\circ} \mathrm{C}\right)$. GC-MS results of revealed that Vietnamese calamondin is rich in limonene (96.925\%), $\beta$-myrcene (1.424 $\%), 1 \mathrm{R}-\alpha$-pinene $(0.561 \%)$, cyclohexene $(0.343 \%)$ and $\alpha$-cubebene $(0.598 \%)$.

\section{ACKNOWLEDGEMENTS}

This study was financially supported by Nguyen Tat Thanh University, Ho Chi Minh City, Vietnam.

\section{CONFLICT OF INTEREST}

The authors declare that there is no conflict of interests regarding the publication of this article.

\section{REFERENCES}

1. E. Christaki, E. Bonos, I. Giannenas and P. Florou-Paneri, Agriculture, 2, 228 (2012);

https://doi.org/10.3390/agriculture2030228.

2. Q.T. Tran, T.T.T. Le, M.Q. Pham, T.L. Do, M.H. Vu, D.C. Nguyen, L.G. Bach, L.M. Bui and Q.L. Pham, Molecules, 24, 895 (2019); https://doi.org/10.3390/molecules24050895.

3. F. Bakkali, S. Averbeck, D. Averbeck and M. Idaomar, Food Chem. Toxicol., 46, 446 (2008);

https://doi.org/10.1016/j.fct.2007.09.106

4. C. Benchaar, S. Calsamiglia, A.V. Chaves, G.R. Fraser, D. Colombatto, T.A. McAllister and K.A. Beauchemin, Anim. Feed Sci. Technol., 145, 209 (2008);

https://doi.org/10.1016/j.anifeedsci.2007.04.014

5. M.G. Miguel, Flavour Fragr. J., 25, 291 (2010); https://doi.org/10.1002/ffj.1961.

6. H. Zhai, H. Liu, S. Wang, J. Wu and A.M. Kluenter, An. Nutr., 4, 179 (2018);

https://doi.org/10.1016/j.aninu.2018.01.005.

7. R.A.Khan, Saudi Pharm. J., 26, 739 (2018); https://doi.org/10.1016/j.jsps.2018.02.015.

8. T.H. Tran, H.H.H. Nguyen, D.C. Nguyen, T.Q. Nguyen, H. Tan, L.T.H. Nhan, D.H. Nguyen, L.D. Tran, S.T. Do and T.D. Nguyen, Processes, 6, 206 (2018); https://doi.org/10.3390/pr6110206.

9. T.H. Tran, P.T.N. Nguyen, T.N. Pham, D.C. Nguyen, T.P. Dao, D.T. Nguyen, N.D. Hai, D.V.N. Vo, X.T. Le, N.T.H. Le and L.G. Bach, IOP Conf. Series Mater. Sci. Eng., 479, 012002 (2019); https://doi.org/10.1088/1757-899X/479/1/012002.

10. L. Wang, V. Ravichandran, Y. Yin, J. Yin and Y. Zhang, Trends Biotechnol., 37, 492 (2019); https://doi.org/10.1016/j.tibtech.2018.10.003.

11. Y. Fu, J. Luo, J. Qin and M. Yang, J. Pharm. Biomed. Anal., 168, 189 (2019); https://doi.org/10.1016/j.jpba.2019.02.027.

12. S. Hu, X. Chen, R. Wang, L. Yang and X. Bai, TrAC Trends Anal. Chem., 113, 340 (2019); https://doi.org/10.1016/j.trac.2018.11.006.

13. S. Dutta, S. Mahalanobish, S. Saha, S. Ghosh and P.C. Sil, Food Chem. Toxicol., 128, 240 (2019); https://doi.org/10.1016/j.fct.2019.04.012.

14. M. Muchtaridi, C.S. Bing, A.S. Abdurrahim and H.A. Wahab, Asian J. Chem., 26, S59 (2014); https://doi.org/10.14233/ajchem.2014.19013.

15. H.Y. Yen and Y.C. Lin, Ind. Crops Prod., 108, 716 (2017); https://doi.org/10.1016/j.indcrop.2017.07.039.

16. G. Mitropoulou, E. Fitsiou, K. Spyridopoulou, A. Tiptiri-Kourpeti, H. Bardouki and M. Vamvakias, LWT-Food Technol., 84, 344 (2017); https://doi.org/10.1016/j.1wt.2017.05.036.

17. F. Wu, Y. Jin, X. Xu and N. Yang, J. Clean. Prod., 159, 85 (2017); https://doi.org/10.1016/j.jclepro.2017.05.010. 
18. A.K. Maurya, S. Mohanty, A. Pal, C.S. Chanotiya and D.U. Bawankule, J. Ethnopharmacol., 212, 86 (2018); https://doi.org/10.1016/j.jep.2017.10.018.

19. S.K. Fagodia, H.P. Singh, D.R. Batish and R.K. Kohli, Ind. Crops Prod., 108, 708 (2017); https://doi.org/10.1016/j.indcrop.2017.07.005.

20. S.A.H. Rizvi, S. Ling, F. Tian, F. Xie and X. Zeng, Ind. Crops Prod., 121, 468 (2018); https://doi.org/10.1016/j.indcrop.2018.05.031.

21. E. Baba, Ü. Acar, C. Öntas, O.S. Kesbic and S. Yilma, Aquaculture, 465, 13 (2016); https://doi.org/10.1016/j.aquaculture.2016.08.023.

22. D. Gonçalves, C.C. Koshima, F.R.M. Batista and C.E.C. Rodrigues, Chem. Eng. Res. Des., 137, 566 (2018); https://doi.org/10.1016/j.cherd.2018.08.008.

23. M.W. Cheong, Z.S. Chong, S.Q. Liu, W. Zhou, P. Curran and B. Yu, Food Chem., 134, 686 (2012); https://doi.org/10.1016/j.foodchem.2012.02.162.

24. M.W. Cheong, D. Zhu, J. Sng, S.Q. Liu, W. Zhou, P. Curran and B. Yu, Food Chem., 134, 696 (2012); https://doi.org/10.1016/j.foodchem.2012.02.139.

25. Q. Li, P. Ning, L. Zheng, J. Huang, G. Li and T. Hsiang, Postharvest Biol. Technol., 58, 157 (2010); https://doi.org/10.1016/j.postharvbio.2010.06.003.

26. T.H. Tran, L.K. Ha, D.C. Nguyen, T.P. Dao, L.T.H. Nhan, D.H. Nguyen, T.D. Nguyen, D.V.N. Vo, Q.T. Tran and L.G. Bach, Processes, 7, 56 (2019);

https://doi.org/10.3390/pr7020056.
27. R. Manouchehri, M.J. Saharkhiz, A. Karami and M. Niakousari, Sustain. Chem. Pharm., 8, 76 (2018); https://doi.org/10.1016/j.scp.2018.03.002.

28. H. Cui, H.W. Pan, P.H. Wang, X.D. Yang, W.C. Zhai, Y. Dong and H.L. Zhou, Ind. Crops Prod., 124, 669 (2018); https://doi.org/10.1016/j.indcrop.2018.08.041.

29. L.P. Stanojevic, N.S. Radulovic, T.M. Djokic, B.M. Stankovic, D.P. Ilicm, M.D. Cakicm and V.D. Nikolic, Ind. Crops Prod., 65, 429 (2015); https://doi.org/10.1016/j.indcrop.2014.10.067.

30. M. Dhobi, V. Mandal and S. Hemalatha, J. Chem. Metrol., 3, 13 (2009).

31. M.A. Ferhat, B.Y. Meklati, J. Smadja and F. Chemat, J. Chromatogr. A, 1112, 121 (2006); https://doi.org/10.1016/j.chroma.2005.12.030.

32. M.N. Boukhatem, M.A. Ferhat, A. Kameli, F. Saidi and H.T. Kebir, Libyan J. Med., 9, 25431 (2014); https://doi.org/10.3402/ljm.v9.25431.

33. L. Cuevas-Glory, E. Sauri-Duch and J.A. Pino, J. Essen. Oil Bearing Plants, 12, 656 (2009); https://doi.org/10.1080/0972060X.2009.10643770.

34. H.S. Choi, J. Agric. Food Chem., 53, 1642 (2005); https://doi.org/10.1021/jf040324x.

35. G.W. Mcgraw, R.W. Hemingway, L.L. Ingram, C.S. Canady and W.B. Mcgraw, Environ. Sci. Technol., 33, 4029 (1999); https://doi.org/10.1021/es9810641. 